\title{
DNA profiling from blood traces present on clothing's and detected by Benzidine test in forensic
}

\section{cases}

\begin{abstract}
Blood is the most common form of biological evidences that encounters in several types of crime i.e. murder, sexual assault/ rape, hit and run cases, tool marks or many types of heinous crime. But in most of the cases, blood on the clothing's or any nearby surfaces are washed off by the perpetrator/accused person in order to destroy the trail of evidences left behind him/her. The stains/doubtful spots are always examined for the presence of blood with the help of presumptive blood tests, such as benzidine test or phenolphthalein test. In this present study, 10 such samples of benzidine-tested cloth and a few blood droplets were lifted from the various surfaces. For DNA isolation, quantification and profiling; un-tested portion of same samples and their respective reference blood samples were collected. A comparative study was conducted between the DNA quantities of benzidine tested portion of samples along with DNA quantity of untested portion of the same samples. Now, all the DNA profiles were compared with the DNA profile obtained from their respective reference blood samples. As a resultant of this study, it was found that DNA profile was not affected by the benzidine test. However, minutiae difference in DNA quantity was observed.
\end{abstract}

Keywords: presumptive blood tests, benzidine test, phenolphthalein test DNA quantitation, DNA profiling, etc
Volume 7 Issue 2 - 2019

\author{
Naresh Kumar,' Amit Chauhan, ${ }^{2}$ Ritika \\ Gupta,' Aanchal Maitray,' Dhruw Sharma,' \\ Shukla SK ${ }^{2}$ \\ 'Forensic Science Laboratory, Home Department, GNCT of \\ Delhi, India \\ ${ }^{2}$ Amity Institute of Forensic Sciences, Amity University, India
}

Correspondence: Naresh Kumar, Forensic Science Laboratory, Home Department, GNCT of Delhi, Rohini, Delhi, India, Tel +91997|918173/954006748, Email nareshkumar2982@yahoo.com

Received: January 22, 2019 | Published: March 15, 2019

\section{Introduction}

In many instances, several types of evidences are recovered in distinct forms or contaminated with any other types of valuable evidences. For forensic investigation purpose, all these evidences have their potential values and often provide link between the victim and accused/suspect. In case of murder, sexual assault or hit and run cases, a few blood drops are frequently recovered from the scene of occurrence. The forensic biologist helps the investigation agencies in the collection of the evidences from the spot of incidence and analysis of the same in the laboratory. Police submit the evidential samples in the Forensic laboratory with a query of DNA analysis, for cases like murder, attempt to murder, rape, concealment of identity of individual/fragmented body parts or where body is transferred after murder from one place to another. In outdoor crimes such as rape/ sexual assault, biological materials transfer from victim to accused/ culprit or vice versa and to the surroundings. ${ }^{1}$ The place of offence must be fixed by the investigation agencies. ${ }^{2}$ Therefore, traces of blood droplets found at crime scene should be processed for DNA profiling. But due to the traced quantity, such samples get consumed in presumptive blood tests, such as Benzidine test and usually not considered for DNA analysis. In few cases where the blood is washed off from the crime scene/surface, it becomes one of the most crucial problems faced in forensic examination of the criminal cases to detect the blood spot. The surfaces are examined for the presence of blood (a necessity) by use of benzidine or phenolphthalein test. The crucial facet is faced when the blood samples are transferred on clothes in very less quantity. Then, it can be directly tested with benzidine that is competent enough to generate complete DNA profiles. BENZIDINE is a greyish-yellow to greyish -red, crystalline solid. It is toxic by ingestion, inhalation, and skin absorption. Combustion produces toxic oxides of nitrogen. Benzidine molecular weight $184.242 \mathrm{~g} / \mathrm{mol}$, an aromatic diamine widely used in industrial processes, that's why, it is used to prepare other chemicals at few instances, it is used for biological analysis. It is also a powerful carcinogen in many animal species. Some presumptive tests have been described for blood stains recognition, ${ }^{3}$ one of the most commonly used tests is Benzidine and its derivative Tetramethylbenzidine (TMB). ${ }^{4}$ It has been observed that the administration of benzidine has been shown to produce tumours in liver, hamster liver, and other tissues of exposed animals. ${ }^{5}$ In most cases to ingestion or inhalation of benzidine workers in the industry suffered a tremendously increased risk of bladder cancer. ${ }^{6}$ Many investigators have studied the mutagenicity of benzidine and their substitute in short-term tests such as the Ames test.

Blood-stains from the surfaces should be lifted in such a manner that contamination with inhibitors could be avoided. In few cases where blood stains are found on wall plaster or surface and it is impossible to collect the intact spot from the wall then the blood stain should be collected on sterile saline-damp gauze. DNA analysis becomes more complicated when examination of such samples is conducted after few months/years from sample collection due to pendency of cases. In the present era of modern and advanced technologies, DNA analysing methodology has improved highly. One of the recent and conventional technologies is real time PCR which is widely used technique for quantitation. Real time PCR enabled forensic scientists to analyze the sample including blood, saliva, hair etc., even in small quantity and help in exonerating the suspect with the available evidence. This technique helps in qualitative, quantitative analysis of DNA. It also indicates the presence of inhibitors in the samples. By use of this technique of DNA quantitation in forensic sample, forensic scientists can determine the know how much DNA is present in the sample and how much we must use for conventional PCR. A required number of amplicons is mandatory for complete DNA profiling, otherwise split peaks, false peaks or off ladder alleles will be in the profile. Inhibitors in the sample may directly bind to DNA or interact with DNA polymerases, 
as they are sensitive to inhibitors, subsequently amplification process is obliterated. ${ }^{5}$ The best way to avoid PCR inhibition is to remove the inhibitors from the samples. Physical disruption methods are helpful for successful analysis. The principle of magnetic beads by automate method of applied Bio systems is one of the ways for analyzing such samples. Degraded samples can also affect the autosomal STR resulting in unsuccessful or incomplete DNA profile and can cause false-negative results. ${ }^{6}$ RT-PCR is important part of whole process prior to go for PCR. The microsatellite has been invented for latest DNA technology and it is used for human DNA profiling. Each microsatellite has 4-5 nucleotides. The quantity extracted DNA affects the success of its analysis. Higher amount of DNA more than $15 \mathrm{ng} / \mu \mathrm{l}$ for PCR amplification and gene sequencing more may give the false peaks and off ladder alleles while less than $1 \mathrm{ng} / \mu \mathrm{l}$ DNA may result and allelic drop of large sized markers sizing more than 200 base pairs. The failure to remove inhibitors in the extraction process may result in poor amplification of certain big sized marker or the failure to generate the full and accurate DNA profile or generate falsenegative results. In this study, we used samples including shirt with minute blood stains and blood spot on floor or surfaces. In these cases where sample quantity was very less than it is very crucial to handle the sample properly during isolation. The Qiagen investigator kit is better to avoid such inhibition during isolation of DNA was used. The Quantifiler Duo kit of Applied Bio systems was used to know the quality \& quantity, PCR inhibitors and availability of male DNA in the samples. This method helped to know the quantity of DNA and also the level of degradation in examined forensic sample. ${ }^{7}$

\section{Materials \& methods}

In this study we have taken the sample collected all the samples from the actual scene of occurrence. During the collection of biological materials from crime scene like cemented floor peices where a minute traces of blood was present; hence, it was handled in a scientific way to avoid any contamination or destruction during the collection of sample or the testing it presence of blood. Lifting of blood-stained soil is a difficult task for an expert because separation of blood from soil will not give any DNA profile after the analysis. The samples failed to generate quantity of DNA in Real Time PCR were processed through the Auto mate kit of applied Bio system as per manufacturer protocol. The blood- stained area $2 \times 2 \mathrm{~cm}^{2}$ of gauzed cloth piece collected for examination was to equate the quantity of sample's material for DNA analysis. Each sample for examination was prepared separately using sterile \& disposable tools.

\section{DNA extraction \& quantitation}

The method applied for DNA isolation Qiagen investigator kit for extraction. In this method buffer used a solvent to separate DNA from proteins and cell debris. ${ }^{8}$ Lastly, DNA was dissolved in $40 \mu 1$ TE. ${ }^{9}$ After isolation, DNA concentration of each sample was determined by using Quantifiler ${ }^{\circledR}$ Duo Quantification kit (Applied Bio systems) with 7500 Real Time PCR machine according to the manufacturer's protocols. Quantification Standards were used to determine the DNA quantity in each sample. The kit used, contains three different types of components, namely Taq $\operatorname{Man}^{\circledR}$ (which act as probe for human specific ribonuclease RNA component H1 (RPPH1) gene), human male specific Sex-determining region Y (SRY) gene and an Internal Positive Control (IPC). ${ }^{10}$

\section{Amplification of DNA \& analysing}

Effects of PCR inhibitors are known to us and therefore, effective measures were adopted to avoid them. Autosomal STRs were amplified using AmpFlSTR ${ }^{\circledR}$ global filer ${ }^{\circledR}$ TM PCR amplification kit (Applied Bio systems) according to the provided protocol. ${ }^{11}$ Amplified samples, now referred as amplicons, were loaded onto ABI $3500 \mathrm{XL}$ genetic analyzer having Gene Mapper IDX 1.4 software for analysis. STR profiles that have been generated, were analyzed for all the samples. The degraded samples showing false peak profiles or allelic drop-out in big sized markers were further processed. ${ }^{12-14}$

\section{Results \& discussion}

As per the resultant of this study, it was found that the use of benzidine for detection of blood from the spots observed at crime scene, affects the quality and quantity of DNA on a scale of $n g / \mu 1$. this difference between the obtained DNA quantity was observed at every types of surface in between the use of benzidine and without use of benzidine..$^{15}$ During the examination of first (cloth piece) sample in which bezidine was not used, $0.89 \mathrm{ng} / \mu \mathrm{l}$ quantity of DNA was obtained while with use of benzidine $0.45 \mathrm{ng} / \mu$ l quantity of DNA was obtained. It signify the difference between the obatined quantity of DNA. During the analysis of sample no. 4 (wall plaster), minimum DNA quantity was obtained in both of manners. It's an indication that the carrier surface also affect the DNA quantity. The obtained values of DNA quantity with the use of benzidine and without benzidine are given below in Table 1. From the results, it was also observed that samples have given the minimum amount of DNA recovered from the samples as the concentration of surface of deposition material were higher that's why only a few of the samples were able to generate the proper profile otherwise it has given the of samples for DNA examination. It is very important to obtain appropriate quality \& quantity of DNA for identification from the putrefied and unidentified dead bodies. The presence of multiple peaks and imbalance of peak height was noticed due the impact of the benzidine test. Profile generated showing 15 markers from the benzidine tested cloth piece using 24 markers global filer Kit is given below in Figure 1. The generated profile is showing 9 markers from the benzidine tested cloth piece using 24 markers global filer Kit. The graphical presentation is given below in Figure 2.

Table I A comparative table between the obtained quantity of DNA without use of benzidine and by use of benzidine

\begin{tabular}{lll}
\hline $\begin{array}{l}\text { Sample } \\
\text { No }\end{array}$ & $\begin{array}{l}\text { Without use of benzidine/ } \\
\text { quantity obtained on } \mathrm{ng} / \mu \mathrm{l}\end{array}$ & $\begin{array}{l}\text { After use of benzedine/ } \\
\text { quantity obtained on } \mathrm{ng} / \mu \mathrm{l}\end{array}$ \\
1 & $0.89 \mathrm{ng} / \mu \mathrm{l}$ & $0.45 \mathrm{ng} / \mu \mathrm{l}$ \\
2 & $3.23 \mathrm{ng} / \mu \mathrm{l}$ & $2.32 \mathrm{ng} / \mu \mathrm{l}$ \\
3 & $0.33 \mathrm{ng} / \mu \mathrm{l}$ & $0.21 \mathrm{ng} / \mu \mathrm{l}$ \\
4 & $0.09 \mathrm{ng} / \mu \mathrm{l}$ & $0.06 \mathrm{ng} / \mu \mathrm{l}$ \\
5 & $1.22 \mathrm{ng} / \mu \mathrm{l}$ & $0.88 \mathrm{ng} / \mu \mathrm{l}$ \\
6 & $0.22 \mathrm{ng} / \mu \mathrm{l}$ & $0.12 \mathrm{ng} / \mu \mathrm{l}$ \\
7 & $4.23 \mathrm{ng} / \mu \mathrm{l}$ & $2.27 \mathrm{ng} / \mu \mathrm{l}$ \\
8 & $5.22 \mathrm{ng} / \mu \mathrm{l}$ & $3.23 \mathrm{ng} / \mu \mathrm{l}$ \\
9 & $1.23 \mathrm{ng} / \mu \mathrm{l}$ & $0.44 \mathrm{ng} / \mu \mathrm{l}$ \\
10 & $3.27 \mathrm{ng} / \mu \mathrm{l}$ & $3.11 \mathrm{ng} / \mu \mathrm{l}$ \\
\hline
\end{tabular}




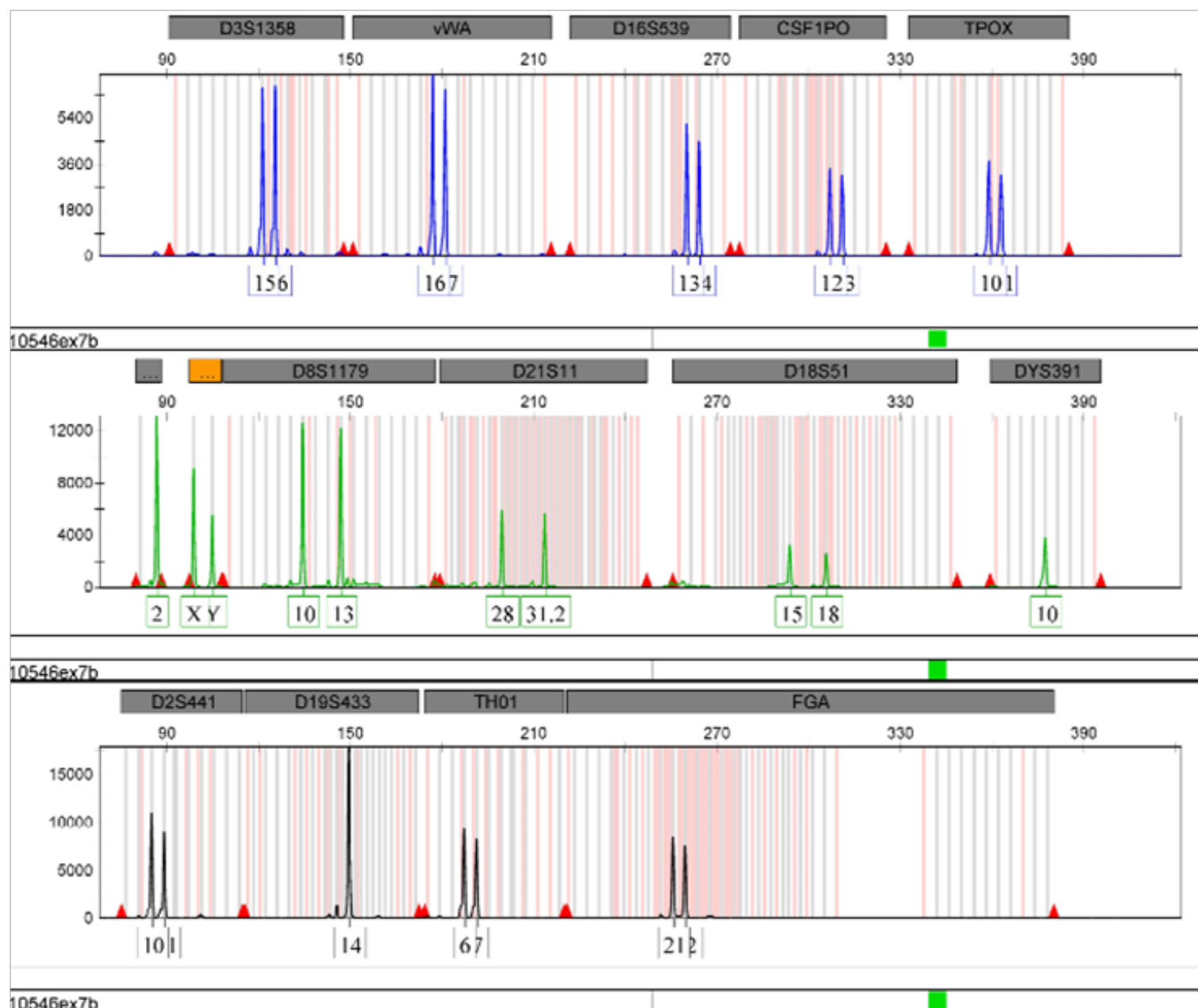

Figure I Profile generated showing 15 markers from the benzidine tested cloth piece using 24 markers global filer kit.

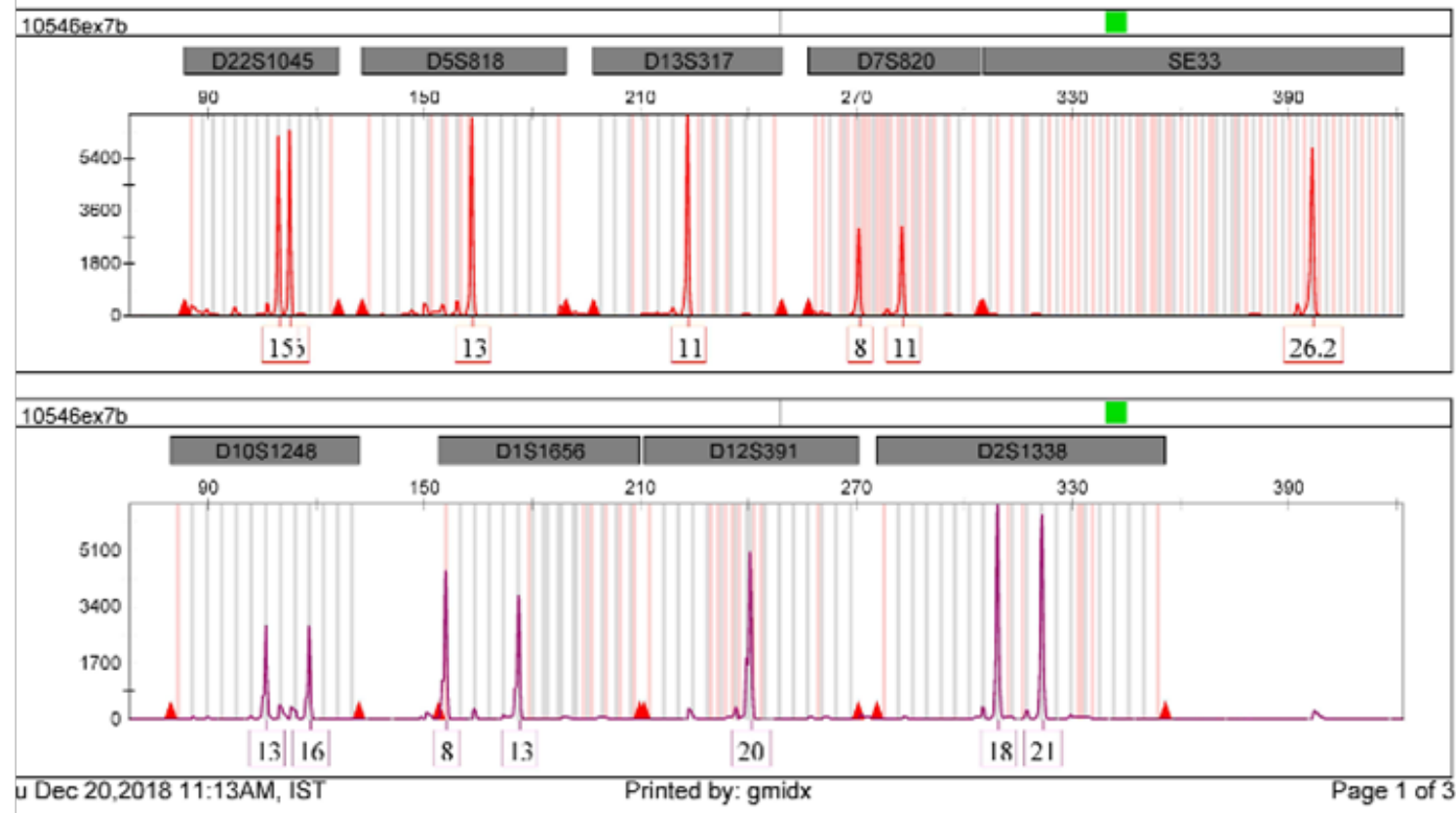

Figure 2 Profile generated showing 9 markers from the benzidine tested cloth piece using 24 markers global filer kit. 


\section{Conclusion}

According to the obtained resultant of this study, it was concluded that the quantity of the DNA is affected by the use of benzidine. The quantity of DNA is also affected by the absorbent surface at which blood was recovered i.e. floor, wall plaster, cloth types, blood mixed with soil etc. However, DNA profile is not affected by the use of benzidine test, phenolphthalein test/or by use of any other chemical that is used for blood detection. ${ }^{16}$ It was also observed that a part/piece of cloth that is suspected to have the blood spots; should be carefully examined and the use of benzidine or appropriate chemical should be use on a small portion so that the higher quantity of DNA could obtain. Except of it, DNA profile will be obtained in proper form and will provide sufficient amount of information about the deceased. Now a day, use of DNA is frequently adopted it identify the victim from the human remains after an accidental/deliberately fire, arson fire or mass disaster has become a standard technique in the scientific community.

\section{Source of funding}

NA.

\section{Ethical clearance}

Not required.

\section{Acknowledgments}

None.

\section{Conflicts of interest}

The author declares that there are no conflicts of interest.

\section{References}

1. Fragman DI, DHKJS. The Law and Science of expert testomony. $2^{\text {nd }}$ Edition. West publishing co. Saint paul. 1997.

2. Ludes B, Pfetzinger HaMP. DNA fingerprinting and tissue after varible postmortem periods. Journal of forensic science jfsca. 1993;38(3):686-690.

3. Tsai YL, Olson BH. Detection of low numbers of bacterial cells in soils \& sediments by Polymerase Chain Reaction. Appl Environ Microbiol. 1992;58(2):754-757.
4. Butler JM. Forensic DNA typing, biology, technology and genetics of STR markers. $2^{\text {nd }}$ Edition. New York: Elsevier Academic Press. 2005.

5. Del Rio SA, Marino MA, Belgrader P. PCR-based human leukocyte antigen (HLA) DQ Alpha typing of blood stained light and dark blue denim fabric. J Forensic Sci. 1996;41(3):490-492.

6. Thompson WC, Taroni F, Aitiken C. How the probability of a false positive affects the value of DNA evidence. Forensic Sci. 2003;48(1):47-54.

7. Richard ML, Frappier R, Newman J. Developmental validation of a real-time quantitative PCR assay for automated quantification of human DNA. Forensic Science. 2003;48:1044-1046.

8. Ladd C, Bourke M, Scherczinger C, et al. A PCR-based strategy for ABO genotype determination. Forensic Sci. 1996;41(1):134-137.

9. Wang WG, Kumar P, Schwarz M, et al. PCR amplification of 40-year paraffin-embedded tumour-tissues-comparison of 4 different DNA extraction and purification methods. Int J Oncol. 1994;5(3)453-457.

10. Barrot C. Comparison of identifiler, identifiler plus and minifiler performance in an initial paternity testing study on old skeletal remains at the forensic and legal medicine area of the government of Andorra (Pyrenees). Forensic Science International: Genetics Supplement Series. 2011;3(1):15-16.

11. Moreira D. Efficient removal of PCR inhibitors using agarose-embedded DNA preparations. Nucleic Acids Research. 1998;26(13):3309-3310.

12. Tsai YL, Olson BH. Rapid method for separation of bacterial DNA from humic substances in sediments for polymerase chain reaction. Appl Environ Microbiol. 1992;58(7):2292-2295.

13. Lakay FM, Botha A, Prior BA. Comparative analysis of environmental DNA extraction and purification methods from different humic acidrich soils. Appl Microbiol. 2007;102(1):265-273.

14. Shahzad MS. Effect of blood stained soils and time period on DNA and allele drop out using Promega 16 Powerplex Kit. Forensic Science International Genetics Supplement Series. 2009;2(1):161-162.

15. Vandewoestyne M, Lepez T, Van Hoofstat D. Evaluation of a visuaization assay for blood on forensic evidences. Journal of forensic Sciences. 2015;60(3):701-707.

16. Tobe SS, Watson N, Daeid NN. Evaluation of six presumptive tests for blood, their specificity and effect on high molecular-weight DNA. Journal of forensic Sciences. 2017;53(2):102-109. 